\title{
A revisão judicial das decisões proferidas pelo Conselho Administrativo de Defesa Econômica*
}

\author{
The judicial review of decisions \\ rendered by the Brazilian \\ Administrative Council of \\ Economic Defense
}

\author{
Amanda Karolini Burg** \\ Everton das Neves Gonçalves ${ }^{* * *}$ \\ Joana Stelzer ${ }^{* * * *}$
}

* Artigo recebido em 18 de julho de 2018 e aprovado em 22 de agosto de 2018. DOI: http://dx.doi.org/10.12660/rda.v278.2019.79033.

** Universidade Federal de Santa Catarina, Florianópolis, SC, Brasil. E-mail: amandakburg@ hotmail.com.

Mestranda na área de direito internacional e sustentabilidade pela Universidade Federal de Santa Catarina (UFSC). Pós-graduada em direito processual civil pela Academia Brasileira de Direito Constitucional (ABDConst). Graduada em direito pela Faculdade Cenecista de Joinville (FCJ).

*** Universidade Federal de Santa Catarina, Florianópolis, SC, Brasil. E-mail: evertong@vetorial. net.

Mestre em instituições jurídico-políticas pela Universidade Federal de Santa Catarina (UFSC), doutor em direito pela Universidade Federal de Minas Gerais (UFMG), doutor em direito internacional econômico pela Universidade de Buenos Aires (UBA), professor de direito econômico e de análise econômica do direito nos cursos de graduação em direito e em economia da UFSC, professor titular credenciado no Programa de Pós-Graduação em Direito da UFSC, coordenador do Grupo de Pesquisa no CNPq e do Centro de Estudos Jurídicos e de Gestão do Desenvolvimento (CEJEGD). 


\section{RESUMO}

Neste trabalho busca-se verificar se, e em que medida, as decisões proferidas pelo Conselho Administrativo de Defesa Econômica (Cade) no controle estrutural e de condutas podem ser revisadas pelo Poder Judiciário. A metodologia de abordagem é indutiva; quanto ao método de procedimento, tem-se o monográfico; a técnica de pesquisa é documental e bibliográfica. Não há consenso acerca da natureza, discricionária ou não, das decisões proferidas pelo Cade. Mesmo assim, por meio de dados quantitativos e qualitativos, decorrentes de pesquisas empíricas elaboradas pela Sociedade Brasileira de Direito Público (SBDP) e por pesquisadores vinculados ao Conselho Nacional de Justiça (CNJ), é possível concluir que as decisões do Cade são objeto de revisão, inclusive de mérito, perante o Poder Judiciário.

\section{PALAVRAS-CHAVE}

Conselho Administrativo de Defesa Econômica - revisão judicial princípio da inafastabilidade da jurisdição - controle de atos de concentração - controle de condutas

\section{ABSTRACT}

This paper aims to verify if, and to what extent, the decisions of the Brazilian Administrative Council of Economic Defense (Cade) can be reviewed by the Judiciary. The investigate methodology is inductive, the procedure method is monographic; and research technic is documental e bibliographical. There is no consensus if the decisions of the Cade are discretionary. Nevertheless, through quantitative and qualitative data, derived from empirical researches by the Brazilian Society of Public Law (SBDP) and by researchers of the Justice National Council (CNJ), it is possible to conclude that the decisions of the Brazilian Administrative Council of Economic Defense are subject to judicial review, even by merit.

**** Universidade Federal de Santa Catarina, Florianópolis, SC, Brasil. E-mail: contatojoana@ yahoo.com.br.

Doutora e mestre em direito pela Universidade Federal de Santa Catarina (UFSC). Pósdoutorado em direito pela Universidade de São Paulo (USP). Professora associada I credenciada no Programa de Pós-Graduação em Direito da Universidade Federal de Santa Catarina (PPGD/UFSC). Coordenadora no Núcleo de Estudos em Fair Trade/Comércio Justo (Neft) do Centro Sócio Econômico (CSE/UFSC). 


\section{KEYWORDS}

Brazilian Administrative Council of Economic Defense - judicial review - inevitable jurisdiction principle - merger control - control of anticompetitive conducts

\section{Introdução}

Partindo da perspectiva de que a Constituição da República Federativa do Brasil de 1988 (CRFB/88) garante o acesso à justiça e a inafastabilidade da jurisdição de forma ampla, busca-se verificar se a previsão doutrinária e a prática dos tribunais admitem que os atos administrativos emitidos pelo Conselho Administrativo de Defesa Econômica (Cade) sejam revisados judicialmente, inclusive, no que tange aos juízos de conveniência e de oportunidade. De forma sintética, busca-se analisar se, e em que medida, tais decisões são passíveis de revisão perante o Poder Judiciário brasileiro.

Nesse sentido, tem-se como objetivo geral constatar se as decisões proferidas pelo Cade no âmbito dos procedimentos de apuração e julgamento de condutas que possam caracterizar infrações à ordem econômica brasileira e de análise de atos de concentração vêm sendo revisadas pelo Poder Judiciário pátrio. Por sua vez, são objetivos específicos: (i) descrever os procedimentos administrativos passíveis de instauração perante o Cade, bem como as decisões deles decorrentes, (ii) delinear os contornos do princípio da inafastabilidade da jurisdição, relacionando-o a posições doutrinárias acerca da revisão judicial dos atos administrativos, e (iii) apresentar dados quantitativos e qualitativos acerca da revisão pelo Poder Judiciário das decisões proferidas pelo Cade.

A fim de alcançar os objetivos propostos, o artigo se encontra estruturado em quatro tópicos, para além da presente introdução e das considerações finais. No tópico 2 são apresentados os procedimentos passíveis de instauração perante o Cade, os quais se encontram regulamentados no art. 48, da Lei no $12.529 / 2011$. Já o tópico 3 dedica-se às questões inerentes ao cenário constitucional atual, o qual garante, de forma expressa, o acesso à justiça. Nesse tópico depreende-se que o acesso à justiça, garantido de forma ampla e incondicionada, torna possível a discussão acerca da revisão judicial, inclusive de mérito, dos atos administrativos. No tópico 4, por sua vez, discute-se a possibilidade de revisão judicial das decisões administrativas proferidas pelo 
Cade. Nesse tópico são explorados temas como a natureza jurídica das decisões proferidas pela autoridade antitruste, bem como a extensão da revisão judicial, sob o ponto de vista doutrinário. Por fim, no tópico 5 são analisados os dados empíricos acerca da revisão judicial das decisões administrativas em comento.

A metodologia de abordagem é indutiva na medida em que parte de dados da realidade, captados via pesquisa indireta, para chegar a uma conclusão geral e, quanto ao método de procedimento, tem-se o monográfico; a técnica de pesquisa é documental e bibliográfica. Conclui-se que as decisões proferidas pelo Cade têm sido revisadas pelo Poder Judiciário.

\section{Dos procedimentos instaurados perante o Cade no controle estrutural e de condutas}

Com a entrada em vigor da Lei no 12.529/2011, o Sistema Brasileiro de Defesa da Concorrência (SBDC) passou a ser composto pelo Conselho Administrativo de Defesa Econômica e pela Secretaria de Acompanhamento Econômico (Seae). Ao Cade, composto pelo Tribunal Administrativo de Defesa Econômica (Tade), pela Superintendência-Geral (SG) e pelo Departamento de Estudos Econômicos (DEE), compete a atividade judicante. ${ }^{1}$ Já a Seae se restringia à advocacia da concorrência. ${ }^{2}$

Salienta-se que, com a entrada em vigor do Decreto no 9.266/2018, ${ }^{3}$ a Seae foi extinta, com a consequente distribuição de suas competências entre a Secretaria de Promoção da Produtividade e Advocacia da Concorrência (Seprac) - voltada à advocacia da concorrência - e a Secretaria de Acompanhamento Fiscal, Energia e Loteria (Sefel) - voltada à formulação

1 BRASIL. Lei $n^{-}$12.529, de 30 de novembro de 2011. Estrutura o sistema brasileiro de defesa da concorrência. Disponível em: <www.planalto.gov.br/ccivil_03/_ato2011-2014/2011/Lei/ L12529.htm>. Acesso em: 9 jul. 2018.

2 FORGIONI, Paula A. Os fundamentos do antitruste. 8. ed. rev. e atual. São Paulo: Revista dos Tribunais, 2015.

3 BRASIL. Decreto nº 9.266, de 15 de janeiro de 2018. Altera o Decreto nº 9.003, de 13 de março de 2017, que aprova a Estrutura Regimental e o Quadro Demonstrativo dos Cargos em Comissão e das Funções de Confiança do Ministério da Fazenda, remaneja cargos em comissão e funções de confiança, substitui cargos em comissão do Grupo-Direção e Assessoramento Superiores DAS por Funções Comissionadas do Poder Executivo - FCPE, e altera o Decreto nº 9.075, de 6 de junho de 2017, que dispõe sobre a composição e as competências da Comissão de Financiamentos Externos. Disponível em: <www.planalto.gov.br/ccivil_03/_ato2015-2018/2018/ decreto/D9266.htm>. Acesso em: 3 ago. 2018. 
e execução da política fiscal, de políticas públicas no setor de energia e de regulação de loterias. ${ }^{4}$

Tradicionalmente, os sistemas antitruste podem controlar as estruturas de mercado, visto que, na prática, o idealizado sistema de concorrência perfeita inexiste; assim como as condutas dos agentes econômicos em mercado (agindo, ou não, para perpetuar práticas infracionais ao mercado); ainda, pode ser avaliado, pelos sistemas, o desempenho dos players. Trata-se do conhecido modelo "estrutura-conduta e desempenho (ECD)". ${ }^{5}$

Por força do disposto no art. 1으, da Lei no 12.529/2011, segundo o qual o SBDC se encontra voltado à prevenção e à repressão das infrações contra a ordem econômica, ${ }^{6}$ é possível depreender que o Brasil adota sistema de proteção dúplice da concorrência, voltado à análise estrutural, incluindo o desempenho empresarial e de condutas. Nesse sentido:

O sistema da lei brasileira é um sistema híbrido. A Nova Lei Antitruste Brasileira (NLAB), também conhecida como Nova Lei de Defesa da Concorrência (LDC), aprovada em 5-10-2011 e em vigor desde 29 de maio de 2012, preservou o enfoque duplo de atuação (condutas e estruturas) e tipificou as infrações à ordem econômica em seu art. $36 .^{7}$

O controle estrutural se consubstancia na atuação preventiva do Cade, em que este "[...] aprova operações societárias, como incorporação ou fusão, e demais atos de que possa decorrer prejuízo à concorrência ou dominação de mercado" ${ }^{8}$ Já o controle de condutas se relaciona com a atuação repressora

4 BRASIL. Ministério da Fazenda. Secretaria de Acompanhamento Econômico - Seae. Disponível em: <www.fazenda.gov.br/orgaos/seae>. Acesso em: 3 ago. 2018.

5 "O paradigma estrutura-conduta-desempenho (ECD) considera a concentração como aspecto central na definição das estruturas de mercado, representando um papel importante na definição do desempenho alocativo dos mercados. Os fatores estruturais são aqueles associados aos aspectos menos mutantes nas indústrias: concentração, barreiras à entrada, diversificação e verticalização das empresas, diferenciação de produto, concorrência internacional. A maior parte desses elementos apresenta interdependência e, de fato, a concentração parece estar relacionada com a maior parte dos fatores." Ver ROCHA, Frederico. Dinâmica da concentração de mercado na indústria brasileira, 1996-2003. Economia e Sociedade, Campinas, v. 19, n. 3 (40), p. 477-498, dez. 2010. p. 478. Disponível em: <https://periodicos.sbu.unicamp.br/ojs/index. php/ecos/article/view/8642677/10157>. Acesso em: 9 jul. 2018.

6 Brasil, Lei n⿳⺈ 12.529, de 30 de novembro de 2011, op. cit.

7 GABAN, Eduardo Molan; DOMINGUES, Juliana Oliveira. Direito antitruste. 4. ed. São Paulo: Saraiva, 2016. p. 86.

8 COELHO, Fábio Ulhoa. Curso de direito comercial: direito de empresa. 12. ed. São Paulo: Saraiva, 2011. v. 3, p. 43. 
do referido órgão que "[...] julga os processos administrativos pertinentes à infração da ordem econômica, impondo sanções às pessoas que incorrerem em conduta ilícita". 9

Nesse cenário normativo, no qual o Cade atua preventiva e repressivamente, com vistas à proteção da concorrência, a Lei Antitruste Nacional vigente previu, em seu art. 48, incisos I a VI, seis procedimentos administrativos passíveis de instauração perante o Conselho, tendo como objetivo a prevenção, a apuração, bem como a repressão de infrações à ordem econômica. São eles: (i) o procedimento preparatório de inquérito administrativo para apuração de infrações à ordem econômica, (ii) o inquérito administrativo para apuração de infrações à ordem econômica, (iii) o processo administrativo para imposição de sanções administrativas por infrações à ordem econômica, (iv) o processo administrativo para análise de ato de concentração econômica, (v) o procedimento administrativo para apuração de ato de concentração econômica, e (vi) o processo administrativo para imposição de sanções processuais incidentais. ${ }^{10}$

Em decorrência das funções preventiva e repressora exercidas pelo Cade, os referidos procedimentos podem ser divididos em dois grupos, na medida em que se relacionam: (i) com a apuração e o julgamento de condutas que possam caracterizar infrações à ordem econômica, ou (ii) com a análise de atos de concentração, nas hipóteses legais.

O primeiro grupo de procedimentos, voltado à apuração e julgamento de condutas que possam caracterizar infrações à ordem econômica, é composto pelo procedimento preparatório de inquérito administrativo para apuração de infrações à ordem econômica, pelo inquérito administrativo para apuração de infrações à ordem econômica e, por fim, pelo processo administrativo para imposição de sanções administrativas por infrações à ordem econômica. Sobre o cabimento de cada um dos procedimentos, ensina Forgioni:

(i) caso a Superintendência-Geral tenha dúvidas quanto à competência do Cade para apreciar a questão, dará início ao procedimento preparatório de inquérito administrativo para apuração de infrações à ordem econômica (art. 66, §2o); (ii) caso a Superintendência-Geral entenda haver indícios suficientes, determinará desde logo a abertura de "Processo

9 Ibid., p. 43.

10 Brasil, Lei no 12.529, de 30 de novembro de 2011, op. cit. 
administrativo para imposição de sanções administrativas por infrações à ordem econômica"; ou (iii) na hipótese de concluir que não há indícios suficientes para a instauração de processo administrativo, a Superintendência-Geral determinará a abertura de Inquérito administrativo para apuração de infrações à ordem econômica. ${ }^{11}$ [grifo no original]

Por sua vez, o segundo grupo de procedimentos, que engloba a análise de atos de concentração, é composto pelo processo administrativo para análise de ato de concentração econômica, pelo procedimento administrativo para apuração de ato de concentração econômica e pelo processo administrativo para imposição de sanções processuais incidentais.

O processo administrativo para análise de ato de concentração terá início com a submissão, pelas partes envolvidas na negociação, do ato de concentração perante o Cade, quando preenchidos os requisitos legais de submissão. ${ }^{12}$ No que tange aos demais procedimentos, tem-se que:

A Lei Antitruste prevê, ainda, a existência de dois outros ritos: (i) procedimento administrativo para apuração de ato de concentração econômica e (ii) processo administrativo para imposição de sanções processuais incidentais. Embora a Lei não seja clara a esse respeito, presume-se que o primeiro tem lugar para investigar se determinada operação econômica deveria ter sido submetida à sua apreciação do Cade, nos termos do art. 88, e não foi. O segundo relaciona-se ao descumprimento de deveres ancilares das empresas representadas ou que pleiteiam a aprovação de operação de concentração econômica. ${ }^{13}$

Em cada um dos procedimentos administrativos elencados são proferidas decisões de natureza administrativa, de acordo com as competências do órgão emissor que compõe o Cade. Em regra, essas decisões não são passíveis de revisão pelo Poder Executivo, nos termos do art. 9, §2o e do art. 61, §3으, ambos da Lei nº 12.529/2011. ${ }^{14}$ Todavia, trata-se de decisões passíveis de criar prejuízos às partes envolvidas, uma vez que podem: (i) ensejar a aprovação integral, a aprovação parcial ou a reprovação de atos de concentração,

Paula A. Forgioni, Os fundamentos do antitruste, op. cit., p. 147.

Brasil, Lei no 12.529, de 30 de novembro de 2011, op. cit.

Paula A. Forgioni, Os fundamentos do antitruste, op. cit., p. 148.

Brasil, Lei n⿳ำ 12.529, de 30 de novembro de 2011, op. cit. 
(ii) obrigar às partes a submeter determinada operação de concentração perante o Cade, (iii) resultar na imposição de sanções processuais incidentais, (iv) reconhecer a prática de infração à ordem econômica, com a aplicação das penas legais etc. Para além das referidas decisões, o Cade pode, ainda, firmar compromissos de cessação de condutas, bem como celebrar acordos em controle de concentração e acordos de leniência.

No Brasil, tanto a persecução antitruste quanto a decisão no Tade são administrativas; portanto, o SBDC é institucionalizado administrativamente e não judicialmente; ou seja, como autarquia que é, o Cade e, especialmente, o Tade, em sua atuação, poderão sofrer o "crivo", por assim dizer, do Poder Judiciário. As decisões exaradas pelo Cade são, na verdade, títulos executivos extrajudiciais a serem, eventualmente, pelo descumprimento das mesmas, submetidos à ação da específica Procuradoria, que atua no Tribunal, de forma a judicializá-los para fins de que o Juízo Federal competente determine ou não seu cumprimento. Destarte, as decisões do Cade, para além de seu cumprimento, podem suscitar decisões judiciais que afastem sua coercitividade administrativa; por exemplo, segundo sejam verificadas nulidades administrativas ou outras possibilidades processuais (como prescrição, decadência etc.) que inviabilizem a aplicação judicialmente coercitiva da determinação administrativa do Cade.

Daí a necessidade de verificação se tais decisões administrativas são passíveis de impugnação perante o Poder Judiciário.

\section{O acesso à justiça e a possibilidade de revisão judicial das decisões administrativas}

Conforme disposto no art. 5o, da $\mathrm{CRFB} / 88$, 15 "A lei não excluirá da apreciação do Poder Judiciário lesão ou ameaça ao direito". Trata-se do Princípio do Acesso à Justiça, também conhecido como Princípio da Inafastabilidade da Jurisdição e, ainda, como Princípio do Direito de Ação. $\mathrm{O}$ acesso à justiça decorre diretamente do vetor da legalidade, previsto no art. 5o, inciso II, da CRFB/88. "Por seu intermédio, nenhuma das espécies normativas do art. 59 da Carta de 1988 pode inviabilizar a tutela jurisdicional,

15 BRASIL. Constituição da República Federativa do Brasil de 1988. Disponível em: <www.planalto. gov.br/ccivil_03/constituicao/constituicao.htm>. Acesso em: 9 jul. 2018. 
preventiva ou repressiva, de direito individual, coletivo, difuso ou individual homogêneo". ${ }^{16}$

De acordo com Gonçalves, ${ }^{17}$ a inafastabilidade da jurisdição é uma "tradução" do direito de ação em sentido amplo. Uma vez apresentado específico requerimento perante o Poder Judiciário, este tem o dever de apresentar a devida resposta ao jurisdicionado mesmo que integrando a lei quando de sua lacuna ou, ainda, fazendo-se valer dos consagrados métodos hermenêuticos, quanto à lei existente, ou, ainda, dos Princípios Gerais do Direito, da equidade, dos costumes e da analogia.

De um lado, a inafastabilidade da jurisdição "[...] impede que o legislador restrinja o acesso à ordem jurídica ou ao ordenamento justo $[\ldots]^{\prime \prime} .^{18}$ De outro, "[...] impõe ao juiz o dever de prestar a jurisdição, isto é, garantir a tutela efetiva, a quem detenha uma posição jurídica de vantagem". ${ }^{19} \mathrm{Na}$ mesma toada, José Afonso da Silva ${ }^{20}$ ensina que o texto constitucional revela o monopólio da jurisdição pelo Poder Judiciário, bem como a possibilidade de invocar a atividade jurisdicional sempre que o sujeito tenha lesado ou simplesmente ameaçado um direito seu.

É da perspectiva do acesso à justiça, direito a ser garantido de forma ampla e incondicionada, que a possibilidade da revisão judicial dos atos administrativos deve ser analisada. Se o Poder Judiciário não pode se furtar à análise das lides perante ele propostas, é possível advogar em nome da tese de que a revisão judicial dos atos administrativos deve ser admitida.

Em que pese a possibilidade de revisão judicial da tomada de decisão administrativa, é sempre interessante lembrar que a própria decisão administrativa, de forma geral, admite, para além do pedido de reconsideração para a autoridade administrativa que exarou o ato questionado, a possibilidade de recurso administrativo em, no máximo, três instâncias recursais. Nada impede, no entanto, que o jurisdicionado acesse, imediatamente, o Poder Judiciário;

16 BULOS, Uadi Lammêgo. Curso de direito constitucional. 9. ed. rev. e atual. de acordo com a Emenda Constitucional n. 83/2004, e os últimos julgados do Supremo Tribunal Federal. São Paulo: Saraiva, 2015. p. 629.

17 GONÇALVES, Marcus Vinicius Rios. Direito processual civil esquematizado. São Paulo: Saraiva, 2011.

18 PINHO, Humberto Dalla Bernadina de. Direito processual civil contemporâneo, volume I: teoria geral do processo. 4. ed. São Paulo: Saraiva, 2012. p. 98.

19 Ibid., p. 98.

20 SILVA, José Afonso da. Curso de direito constitucional positivo. 15. ed. rev. e atual. São Paulo: Malheiros, 1998. 
inclusive, desprezando a possibilidade dos recursos administrativos. Assim reza o texto da Lei 9.784/1999. ${ }^{21}$ Importante frisar, no entanto, que ultrapassadas todas as etapas do devido processo legal administrativo segundo os ritos próprios e com todas as possibilidades de defesa administrativa, a decisão do Tade é, administrativamente, terminativa não amparando recurso administrativo, restando, como afirmado, a constitucional instância judicial. Todavia, a questão envolve polêmicas. Quais os limites a serem observados pelo Poder Judiciário ao julgar reclamação envolvendo atos administrativos? Admite-se o controle de mérito, ou o Judiciário deve se contentar com o controle formal, inerente às noções de legalidade? Afinal, qual é a amplitude de julgamento do magistrado para análise da matéria que se o submete em vista do óbvio descontentamento da parte que se vê afetada pela decisão administrativa? Compete ao juiz federal de primeira instância verificar tão somente questões processuais? Nulidades? Ou, quiçá, o quantum debeatur de uma multa determinada pelo Cade? Ou poderia, ainda, adentrar no mérito administrativo de uma decisão tomada em órgão colegiado (Tade) composto por sete experts com notório saber jurídico-econômico, devidamente sabatinados no Senado Federal e indicados pelo presidente da República? Esses questionamentos são analisados a seguir. Por enquanto, pode-se tão somente concluir que os atos administrativos, de maneira geral, podem ser submetidos à apreciação do Poder Judiciário.

\section{Da possibilidade de revisão judicial das decisões administrativas no Cade e no Tade}

Inicialmente, é preciso consolidar a ideia de que as decisões proferidas pelo Cade se caracterizam como atos administrativos, os quais, segundo Carvalho Filho, se caracterizam pela presença de três elementos:

Em primeiro lugar, é necessário que a vontade emane de agente da Administração Pública ou dotado de prerrogativas desta. Depois, seu conteúdo há de propiciar a produção de efeitos jurídicos com fim

21 BRASIL. Lei 9.784, de 29/01/1999, que regula o processo administrativo no âmbito da Administração Pública Federal. Disponível em: <www.planalto.gov.br/ccivil_03/leis/19784. htm>. Acesso em: 9 jul. 2018. 
público. Por fim, deve toda essa categoria de atos ser regida basicamente pelo Direito Público. ${ }^{22}$

Os atos administrativos podem ser classificados quanto: (i) à "natureza da atividade", sendo de administração ativa, consultiva, controladora, verificadora ou contenciosa, (ii) à "estrutura do ato", sendo concretos ou abstratos, (iii) aos "destinatários do ato", sendo individuais ou gerais, (iv) ao "grau de liberdade da administração em sua prática", sendo vinculados ou discricionários, (v) à "função da vontade administrativa", sendo negociais ou puros, (vi) aos "efeitos", sendo constitutivos ou declaratórios, (vii) aos "resultados sobre a esfera jurídica", sendo ampliativos ou restritivos, (viii) à "situação de terceiros", sendo internos ou externos, (ix) à "composição da vontade produtora", sendo simples ou complexas, (x) à "formação do ato", sendo unilaterais ou bilaterais, (xi) à "natureza das situações jurídicas que criam", sendo atos-regra, atos subjetivos ou atos-condição, e (xii) à "posição jurídica da Administração", sendo de império ou de gestão. ${ }^{23}$

Em relação às decisões administrativas que se apresentam como espécie de ato administrativo, merece destaque a classificação quanto à liberdade da administração em sua prática. A distinção entre atos discricionários e vinculados é essencial à discussão acerca da revisão judicial de atos administrativos.

Desse modo, é importante diferenciar poder vinculado de poder discricionário. Tem-se a prática de um ato vinculado quando "A Administração Pública não é livre para resolver sobre a conveniência do ato, nem sobre o seu conteúdo. Só lhe cabe constatar a ocorrência dos motivos, e, com base neles, praticar o ato". ${ }^{24}$ Diferentemente, há a prática de um ato discricionário sempre que "[...] a lei deixa a autoridade administrativa livre na apreciação do motivo ou do objeto do ato, ou de ambos ao mesmo tempo". ${ }^{25}$ Trata-se da clássica noção de juízo de conveniência e de oportunidade da administração pública.

Feitos esses esclarecimentos conceituais, é importante apresentar a visão da doutrina acerca da plausibilidade de revisão de atos administrativos.

22 CARVALHO FILHO, José dos Santos. Manual de direito administrativo. 28. ed. rev., ampl. e atual. São Paulo: Atlas, 2015. p. 101.

23 MELLO, Celso Antônio Bandeira de. Curso de direito administrativo. 26. ed. rev. e atual. São Paulo: Malheiros, 2009.

24 FAGUNDES, Miguel Seabra. O controle dos atos administrativos pelo Poder Judiciário. 8. ed. Rio de Janeiro: Forense, 2010, p. 92.

25 Ibid., p. 92. 
Quando a impugnação judicial versa sobre questões atinentes à forma/ legalidade do ato administrativo, inexistem grandes questionamentos. É praticamente unânime o entendimento de que compete ao Poder Judiciário analisar a observância dos preceitos legais pela administração quando da prática de um ato administrativo. Nesse diapasão: "Todos os atos administrativos podem submeter-se à apreciação judicial de sua legalidade, e esse é o natural corolário do princípio da legalidade. Em relação aos atos vinculados, não há dúvida de que o controle de legalidade a cargo do Judiciário terá muito mais efetividade" ${ }^{26}$

A dúvida sobre a competência do Poder Judiciário para revisar atos administrativos surge quando da análise do mérito desses atos, ou seja, quando se questionam a oportunidade e a conveniência de determinado ato (poder discricionário).

Grande parte da doutrina não admite a ampla apreciação do mérito do ato administrativo pelo Poder Judiciário. Para Mazza, ${ }^{27}$ apenas o ato desproporcional, que não atendeu aos pressupostos fáticos ensejadores ou que foi praticado sem observância do interesse público, pode ser declarado nulo pelo Poder Judiciário, com a devida remessa do ato à administração, para que esta adote nova decisão. Segundo Carvalho Filho, ${ }^{28}$ “[...] embora louvável a moderna inclinação doutrinária de ampliar o controle judicial dos atos discricionários, não se poderá chegar ao extremo de permitir que o juiz examine a própria valoração administrativa, legítima em si e atribuída ao administrador". No mesmo sentido, Carvalho ${ }^{29}$ admite a atuação do Poder Judiciário "[...] somente no que tange aos aspectos de legalidade, não sendo admitido que Poder Judiciário intervenha nos aspectos de oportunidade e de conveniência que justificaram a prática dos atos administrativos".

Por outro lado, há autores que defendem também a possibilidade de revisão do mérito dos atos discricionários pelo Poder Judiciário. Para Faria, o mérito do ato administrativo "não pode ser excluído da verificação por parte do Poder Judiciário". ${ }^{30}$ Segundo o autor, durante anos, o Poder Judiciário brasileiro se recusou a examinar atos administrativos discricionários e,

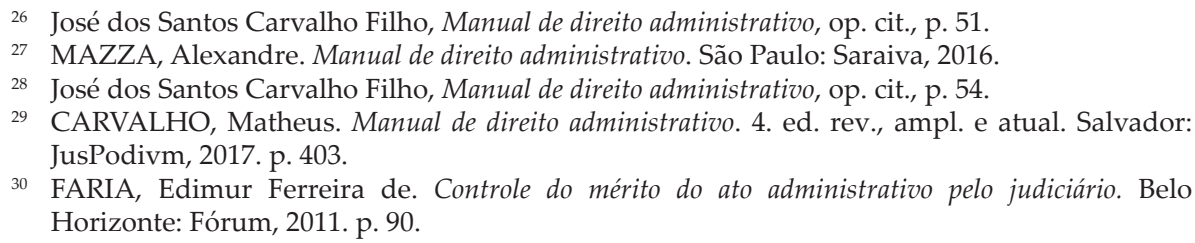


posteriormente, passou a admitir o controle da discricionariedade (ressalvado o mérito do ato); e, atualmente, é cada vez mais comum a prolação de sentenças versando sobre o mérito de atos administrativos impugnados. Advogando pela possibilidade de revisão do mérito dos atos administrativos, Ferraz questiona como harmonizar a suposta impossibilidade de apreciação do mérito do ato administrativo pelo Poder Judiciário com o poder-dever do juiz de coibir o desvio ou o abuso de poder:

Nessa corrente de ideias, parece rematado absurdo, venia concessa dos que em contrário pensam, afirmar a não sindicabilidade judicial do mérito administrativo. Aliás, como harmonizar essa regra vedatória com a pacificamente reconhecida capacidade que tem o juiz de coibir o desvio ou o abuso de poder? Só se chega à constatação de tais patologias com a investigação dos motivos e da motivação do ato administrativo. ${ }^{31}$

Como se pode verificar, boa parte da doutrina ainda advoga em nome da não sindicabilidade judicial do mérito do ato administrativo; entretanto, tal corrente encontra oposição entre doutrinadores e também juízes, que admitem, em certo grau, a revisão judicial dos atos discricionários no que tange à conveniência e à oportunidade. A celeuma se constrói tanto doutrinária como judicialmente no que concerne aos atos administrativos em geral e, também, em relação às decisões do Cade e do Tade.

Em relação aos atos praticados pelo Cade, portanto, a discordância doutrinária reina. Não há consenso quanto à natureza jurídica das decisões proferidas pela autarquia. Consequentemente, inexiste unidade acerca da possibilidade e extensão da revisão judicial. Nesse sentido, disserta Porto:

Questão polêmica que se coloca é se as decisões do Cade seriam de natureza vinculada, ou discricionária, partindo-se do pressuposto de que muitos dos conceitos jurídicos trazidos pela lei antitruste e do artigo 170 da Carta Magna são considerados indeterminados, a saber: o problema da eficiência econômica, mercado relevante, posição dominante, abuso de poder econômico etc., e, por causa disso, os atos administrativos do Cade deveriam ser considerados como atos

31 FERRAZ apud Edimur Ferreira de Faria, Controle do mérito do ato administrativo pelo judiciário, op. cit., p. 248. 
discricionários, trazendo consequências na reapreciação pelo Judiciário, eis que a este somente caberia a revisão do ato discricionário, devido à legalidade e ao mérito (oportunidade e conveniência, diante do interesse público a atingir). De qualquer forma, todo ato administrativo está sujeito ao controle judicial. Se os atos do Cade fossem considerados vinculados, não haveria opções àquela autarquia decidir com base nos critérios de oportunidade e conveniência - algo possível, em se tratando de atos discricionários. Caso fossem considerados atos discricionários, a Administração Pública poderia decidir baseada na oportunidade e conveniência, atitude justificada perante a necessidade de dinamicidade e flexibilidade que lhe são exigidas na aplicação de normas preestabelecidas. ${ }^{32}$

Portanto, em não havendo consenso doutrinário a respeito da discricionariedade ou vinculação dos atos decisórios do Cade, podem ser verificadas divergências quanto à tomada de decisão inerente, v.g., à intensidade do que seja considerado como abuso de poder econômico que, em verdade, se trata de conceito jurídico indeterminado.

Portes, apresentando, especialmente, o pensamento das respeitáveis escolas, mineira e paulista de direito econômico, reitera essa ausência de consenso, lembrando, inicialmente, autoras como Amanda Flávio de Oliveira e Paula Forgioni, a favor da revisão judicial ampla dos atos administrativos:

Tal diferenciação é crucial, porquanto, a princípio, sob a ótica da tradicional classificação dos atos administrativos, os aspectos dos atos administrativos de caráter discricionário escapam ao controle judicial, limitando-se a competência do Poder Judiciário a avaliar a legalidade dos atos (controle formal) e se o ato observou os limites da discricionariedade (exame quanto à razoabilidade na avaliação dos critérios de conveniência e oportunidade). Ao passo que os aspectos vinculados do ato administrativo comportam revisão plena. Amanda Flávio de Oliveira, em "O Direito da Concorrência e o Poder Judiciário", considera serem as decisões do Cade atos administrativos vinculados, passíveis, portanto, de revisão plena. Escorando-se na lição de Eduardo Enterría,

32 PORTO, Catarina Mota de Figueiredo. Decisões do Cade e princípios constitucionais na ordem econômica. Disponível em: <www.fap-pb.edu.br/instituto/arquivos/revista_juridica_2015_ artigo6.pdf $>$. Acesso em: 9 jul. 2018. 
e na linha da atual doutrina administrativista, a autora defende que a partir da evolução dos conceitos de discricionariedade e vinculação diversas situações consideradas anteriormente no âmbito dos atos discricionários passaram a ser consideradas vinculadas - passíveis, portanto, de revisão judicial, sendo um exemplo disso os conceitos jurídicos indeterminados, amplamente utilizados pela Lei 12.529/11. [...] Sustentam, ainda, que mesmo os aspectos discricionários que possam constar da decisão do Cade poderão ser controlados judicialmente pelo critério da razoabilidade e proporcionalidade. Nesse sentido, todas as decisões do Cade estariam sujeitas ao controle amplo, não apenas formal, mas também de mérito, do Judiciário. Filia-se a essa corrente Paula Forgioni, para quem, em um Estado Democrático de Direito, não se admite poder sem controle. Segundo a autora, a revisão judicial é a segurança do cidadão contra eventuais abusos ou enganos cometidos pelo Executivo. [...]. ${ }^{33}$

Ato contínuo, a citada autora chama a atenção para o pensamento de Izabel Vaz que, a sua vez, percebe negativas as limitações à atuação do Tade segundo submissão dos julgados administrativos ao império do Poder Judiciário:

Divergindo dessa posição, Isabel Vaz sustenta que, salvo em caso de ofensa a princípios constitucionais, o mais adequado é que se adote o modelo de jurisdição contida, com o controle apenas formal das decisões do Cade. De acordo com a autora, as autoridades antitruste, no exercício de sua função judicante, estão sujeitas a diversas limitações, tais como a necessidade de motivar o ato decisório, a vinculação aos requisitos legais, dentre outras. Contudo, "a mais avassaladora entre todas as limitações é aquela decorrente da necessidade de se harmonizar as decisões antitruste com as políticas econômicas estabelecidas em um setor". Dessa limitação, isto é, da importância de se conformar as decisões proferidas na seara do Direito Concorrencial com as políticas econômicas adotadas pelo Estado, decorre a necessidade de se adotar

33 PORTES, 2014 apud LIMA, Eduardo Garcia. O controle judicial das decisões do Cade. Revista Eletrônica Sapere Aude. Disponível em: <http://revistasapereaude.org/index.php/edicoes/anosanteriores/ano-4-vol-1-12/ano-4-volume-4-novembro-2015/send/88-11-2015-ano-4-volume4/307-j-o-controle-judicial-das-decisoes-do-cade-pg-180-203>. Acesso em: 9 jul. 2018. 
o modelo de jurisdição contida. Dito de outro modo: tendo em vista que o Cade, ao proferir sua decisão, já buscou adequá-la às políticas econômicas implementadas pelo Estado, convém circunscrever a ação do Judiciário ao controle da legalidade, preservando a integridade do aspecto material da decisão administrativa já proferida. ${ }^{34}$

Pelo que se percebe, da dicotomia entre os que defendem a revisão ampla por parte do Poder Judiciário e os partidários da revisão judicial contida das decisões proferidas pelo Tade resta determinante a natureza jurídica desses atos administrativos - se discricionários ou vinculados. Entendidos como discricionários, poderiam tais atos sofrer o controle judicial meramente formal e na perspectiva da razoabilidade e proporcionalidade da conveniência e oportunidade da tomada de decisão por parte da administração pública.

De outra forma, considerados os atos decisórios do Tade vinculados, estender-se-ia ao Poder Judiciário a capacidade de análise e julgamento do mérito da decisão administrativa.

Em que pese o fato de que, tanto em uma como em outra posição, restará, ao Judiciário, possibilidade constitucional de manifestação como ultima ratio para o apaziguamento social, é de se ponderar que tal intervenção deverá zelar pela excelência na aplicação dos princípios do antitruste, ainda segundo máxima socialmente inclusiva e eficiente própria do princípio da eficiência econômico-social (Pees) ${ }^{35}$ que se defende como forma de tomada de decisão administrativo-jurídica, aproveitando-se racionalmente os escassos recursos, evitando-se o desperdício de meios, subaproveitamento de pessoas

34 Explica, ainda: “Ao lado de Isabel Vaz há também quem defenda que as decisões do Cade não poderiam ser objeto de revisão judicial (salvo sob o aspecto formal), tendo em vista o caráter altamente técnico da decisão. Nesse sentido, por exemplo, a lição de Edilson Nobre, para quem nas situações em que a decisão do Cade apresente conteúdo eminentemente técnico não se mostra adequada a intervenção ilimitada do juiz. Essa corrente, que defende a impossibilidade de revisão do mérito da decisão do Cade, aponta também a economia processual e a maior efetividade da proteção da concorrência que decorreriam dessa vedação, tendo em vista que não se decidiria duas vezes a mesma questão, e que se privilegiaria a solução técnica, dada por espertos no assunto. Outro argumento frequentemente suscitado por esta corrente é o despreparo dos magistrados quanto ao Direito Concorrencial, disciplina relativamente recente, à qual a maioria dos magistrados sequer teve acesso nos bancos da faculdade". Ibid., p. 180-203.

35 GONÇALVES, Everton das Neves; STELZER, Joana. Principle of social and economic efficiency (Psee) at the Brazilians law: the normative and judicial decision taking. Sequencia: Estudos Jurídicos e Políticos, s.l., v. 35, n. 68, p. 261-290, jun. 2014. Disponível em: <https://periodicos. ufsc.br/index.php/sequencia/article/view/2177-7055.2013v35n68p261/26955 . Acesso em: 9 jul. 2018. 
e buscando-se a necessária inclusão social, ainda, mesmo, pensando-se nos reflexos jurídico-político-econômicos de presentes e futuras gerações. Nesse sentido já se vem defendendo alhures a possibilidade da aplicação da análise econômica do direito, seja na criação da norma ou seja na aplicação da mesma pelos players da economia e, mais, ainda, quando da apreciação administrativa (como é o caso da tomada de decisão no âmbito do Cade) como na apreciação judicial de caso in concretu.

Destarte, seja em função de decisão administrativa, no Tade, ou judicial (com jurisdição plena ou contida), em função do Pees, deve-se perquirir pela adjudicação de decisão adequada para a obtenção de máxima felicidade de todos os envolvidos pela decisão administrativa inicialmente tomada pelo Tade e eventualmente discutida em juízo, bem como seu reflexo para as sociedades presente e futura, segundo perspectiva social e economicamente inclusiva, (re)distribuição progressista dos escassos recursos e ação empresarial que vise o lucro como recompensa social de todos os envolvidos na prática empresarial ou que venham a ser, de alguma forma, presente ou futuramente atingidos ou beneficiados. Tal lucro, entretanto, sendo privado, não pode desconsiderar o uso da riqueza social.

Fato é que, para além das discussões teóricas, as decisões proferidas pelo Cade vêm sendo impugnadas perante o Poder Judiciário, sofrendo reformas, inclusive de mérito.

\section{Da revisão judicial das decisões proferidas pelo Cade em números}

Inexistente consenso na doutrina quanto à possibilidade de revisão judicial de atos administrativos, bem como quanto à natureza, discricionária ou vinculada, das decisões proferidas pelo Cade, no presente tópico, busca-se a verificação de dados coletados acerca da frequência pela qual a revisão judicial das decisões administrativas proferidas pelo Cade ocorre no tempo com base em dados da realidade (empíricos).

Primeiramente, são objeto de apreciação os dados apresentados na pesquisa empírica e aplicada realizada a partir de 2009 pelo Cade, pela Federação das Indústrias do Estado de São Paulo (Fiesp) e pela Sociedade Brasileira de Direito Público (SBDP), que deu ensejo à publicação da obra Revisão judicial das decisões do Conselho Administrativo de Defesa Econômica (Cade): Pesquisa 
empirica e aplicada sobre casos julgados pelos Tribunais Regionais Federais (TRFs), Superior Tribunal de Justiça (STJ) e Supremo Tribunal Federal (STF), em 2011. ${ }^{36}$

Trata-se de pesquisa empírica e aplicada, voltada à análise dos acórdãos proferidos pelos Tribunais Regionais Federais da Primeira, Segunda e Quarta Regiões, Superior Tribunal de Justiça e Supremo Tribunal Federal, que tem como objeto decisões proferidas pelo Cade, desde o advento da Lei no 8.884/1994 até abril de 2010 (antes da entrada em vigor da novel Legislação Antitruste). O recorte adotado pelos pesquisadores incluiu: (i) decisões transitadas em julgado nos referidos tribunais, e (ii) decisões já proferidas nos tribunais citados, mas pendentes de recurso perante instâncias superiores. O referido recorte deu ensejo à análise de 52 recursos, decorrentes de 41 processos judiciais distribuídos entre os Tribunais, relacionados com 39 decisões administrativas distintas instauradas perante o Cade.

Em relação aos fatores de entrada ao Poder Judiciário, das 39 decisões administrativas impugnadas judicialmente, 18 versavam sobre atos de concentração (AC) e 21 sobre processos administrativos (PA). Não há, efetivamente, distinção significativa entre a judicialização de questões discutidas em PA e aquelas decididas em AC. Salienta-se que, dos 18 casos relacionados a AC, quatro versavam sobre casos em que houve questionamento acerca da decisão que aprovou a operação de concentração com restrições, nove sobre a questão inerente à aplicação de multa por comunicação intempestiva e quatro sobre o pagamento de taxa para submissão de ato de concentração perante o Cade. O 18 o caso diz respeito à Ação Civil Pública, intentada pelo Ministério Público Federal, com vistas à atuação do Cade em ato de concentração. No que tange às impugnações judiciais decorrentes de PA, dos 21 casos, 10 versavam sobre unimilitância, 5 sobre tabelamento de preço, 1 sobre irregularidades em processo licitatório, 3 sobre cartel, 2 foram ajuizados antes da prolação de decisão final pelo Cade a fim de "trancar" o procedimento administrativo e 1 teve sua decisão anulada administrativamente pelo próprio Cade. ${ }^{37}$

Em relação aos setores envolvidos, em PA as decisões que deram origem a mais processos judiciais foram proferidas no âmbito dos serviços gerais médicos, totalizando 15 em 21 casos. Em AC, o setor que mais deu azo à

36 SOCIEDADE BRASILEIRA DE DIREITO PÚBLICO (SBDP). Revisão judicial das decisões do Conselho Administrativo de Defesa Econômica (Cade): pesquisa empírica e aplicada sobre os casos julgados pelos Tribunais Regionais Federais (TRFs), Superior Tribunal de Justiça (STJ) e Supremo Tribunal Federal (SFT). Belo Horizonte: Fórum, 2011.

37 Ibid., p. 45-47. 
judicialização foi o da indústria mecânica de elevadores, totalizando seis em 18 casos. $^{38}$

No que tange ao tempo médio de tramitação dos processos em questão, verificou-se que estes demoram, em média, cinco anos e três meses para serem analisados. Dos quais, dois anos e dois meses são utilizados na tramitação em primeira instância. ${ }^{39}$

Ao analisar se o resultado das medidas judiciais, sentenças e acórdãos, eram pró ou contra o Cade, percebeu-se que, de 21 decisões finais transitadas em julgado, 10 foram contra a Autarquia Antitruste; ou seja, revisaram o mérito administrativo, anularam a decisão por ilegalidade formal ou anularam, suspenderam ou alteraram o valor da multa; enquanto 11 mantiveram integralmente a decisão administrativa impugnada, sendo, portanto, próCade. De 20 decisões proferidas em primeira instância, 11 foram pró-Cade e nove contra. Destas, apenas três foram revertidas em grau de recurso..$^{40}$

Importante ponto da pesquisa diz respeito à revisão de mérito das decisões proferidas pelo Cade. Em 19 recursos julgado (com resposta não definitiva), apenas cinco resultaram em revisão com modificação da decisão, dos quais três versavam sobre mérito, um sobre forma e um sobre mérito e forma. Por sua vez, entre 22 casos transitados em julgado, 10 resultaram na modificação da decisão, sendo que oito revisaram o mérito, um a forma e um o mérito e a forma. Dos 41 processos distribuídos, sem distinção entre casos transitados em julgado e recursos julgados, foram 15 casos de modificação da decisão do Cade, dos quais 11 resultaram na revisão de mérito, dois de forma e dois de forma e mérito. ${ }^{41}$

A partir dos dados apresentados, a SBDP concluiu que: (i) inexiste tendência genérica de julgamento pró ou contra Cade em relação aos Tribunais avaliados, (ii) em se tratando de casos transitados em julgado, a tendência de manutenção das decisões do Cade perde força, apresentando números próximos ao de revisão, (iii) o nível de reversão das decisões de primeira instância é relativamente pequeno. ${ }^{42}$

Em relação à discricionariedade dos atos praticados pelo Cade, a partir da análise do teor dos julgados, os pesquisadores concluíram que:

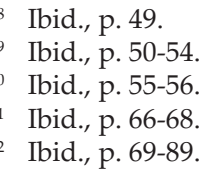


[...] a tecnicidade da decisão do Cade não constitui um argumento considerado pelo Poder Judiciário para afastar a análise do mérito da decisão administrativa. Apenas em quatro casos dentre os analisados argumentou-se no sentido de ser a decisão administrativa estritamente discricionária, não sendo possível a sua modificação judicial. Estes posicionamentos não se consolidaram, uma vez que, em casos que trataram do mesmo tema e que foram julgados em momento posterior, verificou-se a revisão judicial exatamente das mesmas questões pontuadas como discricionárias. ${ }^{43}$ [grifo nosso]

Outra pesquisa que merece destaque é aquela realizada em 2010, por professores e pesquisadores ligados ao Conselho Nacional de Justiça (CNJ), que deu ensejo à publicação do livro Direito regulatório e concorrencial no Poder Judiciário.

Na referida pesquisa foram coletados cerca de 1.400 processos judiciais cujo objeto consistia na impugnação perante o Poder Judiciário de decisões das agências reguladoras e do Cade, com foco na primeira e segunda instâncias.

Uma das primeiras conclusões interessantes da pesquisa diz respeito ao pequeno número de processos transitados em julgados para todas as autarquias. Dos processos relacionados com o Cade, apenas 15,6\% haviam transitado em julgado. Considerando todas as autarquias estudadas, tem-se um tempo médio de tramitação de 36 meses até o trânsito em julgado. O tempo aumenta para 58 meses em casos envolvendo decisão de mérito, e para 69 meses quando o Poder Judiciário anula ou reforma a decisão administrativa. ${ }^{44}$

Quanto ao produto entregue pelo Poder Judiciário, ao contrário da pesquisa anterior, conclui-se que o grau de confirmação das decisões é elevado. Em relação às decisões transitadas em julgado relacionadas ao Cade, tem-se um índice de confirmação de $74 \%$ das decisões administrativas. ${ }^{45}$

A partir de uma perspectiva quantitativa, conclui-se que a revisão judicial das agências reguladoras e do Cade encontra duas sérias deficiências, relacionadas com a demora do processo e com a insegurança jurídica. A questão temporal teria como justificativa: (i) a complexidade dos casos envolvidos

43 Ibid., p. 114.

44 MARANHÃ̃, Juliano Souza de Albuquerque; AZEVEDO, Paulo Furquim; FERRAZ JUNIOR, Tercio Sampaio. Direito regulatório e concorrencial no Poder Judiciário. São Paulo: Singular, 2014. p. 17.

45 Ibid., p. 18. 
e a priorização de casos mais simples, (ii) a necessidade de realização de perícia, (iii) a dúvida sobre o escopo da revisão judicial, bem como (iv) os conflitos de competência. Já a insegurança jurídica encontraria raízes: (i) na ausência de diretrizes relacionas com a concessão de liminares, (ii) na existência de um sistema recursal complexo que admite a rediscussão das questões repetidamente, (iii) na multiplicidade de causas idênticas, e (iv) na dúvida acerca do escopo da revisão. ${ }^{46}$

Por outro lado, qualitativamente, a partir da análise do conteúdo das decisões proferidas no âmbito da revisão judicial das decisões das agências reguladoras e do Cade, foram elencados os seguintes problemas: (i) sobrevalorização de questões processuais, relacionada especialmente com a intolerância em face da informalidade administrativa, bem como com o desconhecimento dos procedimentos específicos de cada autarquia, (ii) falta de expertise técnica, (iii) viés privatista, na medida em que os juízes nem sempre sabem como lidar com questões inerentes a políticas públicas e ao papel desempenhado pelas agências, e (iv) insensibilidade às razões regulatórias, que resulta num refúgio ao formalismo. ${ }^{47}$

Por fim, dados mais recentes demonstram que, desde a entrada em vigor da Lei no 12.529/2011, o número de ações propostas perante o Cade aumentou. Comparando-se os anos de 2012, primeiro ano de aplicação da nova legislação, e 2016 é possível verificar que o número de ações propostas contra o Cade passou de 39 para 143. Nesse sentido, o gráfico n⿳o 1 , retirado do Balanço do Cade de 2016. 
Gráfico 1

Comparativo de ações judiciais por ano

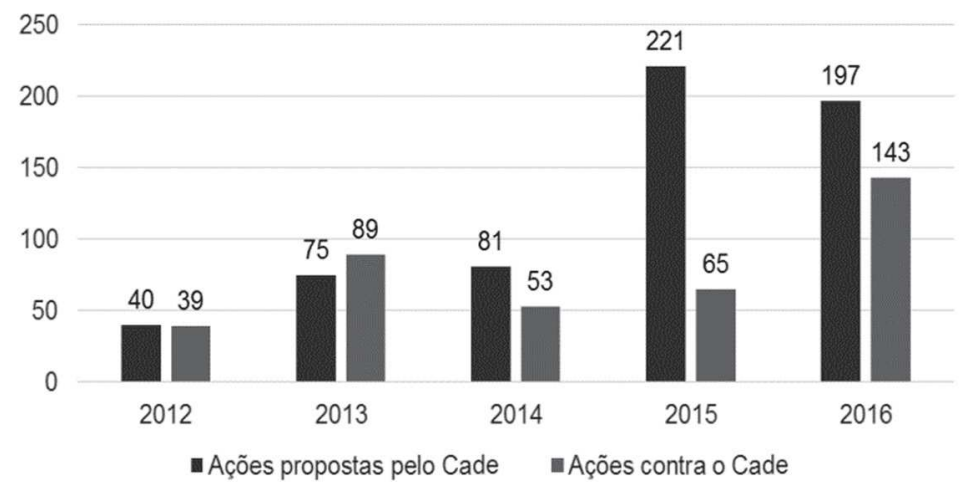

Fonte: Balanço do Cade de $2016 .{ }^{48}$

Por outro lado, o êxito da autarquia perante o Poder Judiciário vem se mantendo estável desde 2012. Entre 2012 e 2016, o Cade obteve decisões favoráveis no Poder Judiciário, em média, em 72,2\% dos casos.

Gráfico 2

Êxito do Cade no Judiciário

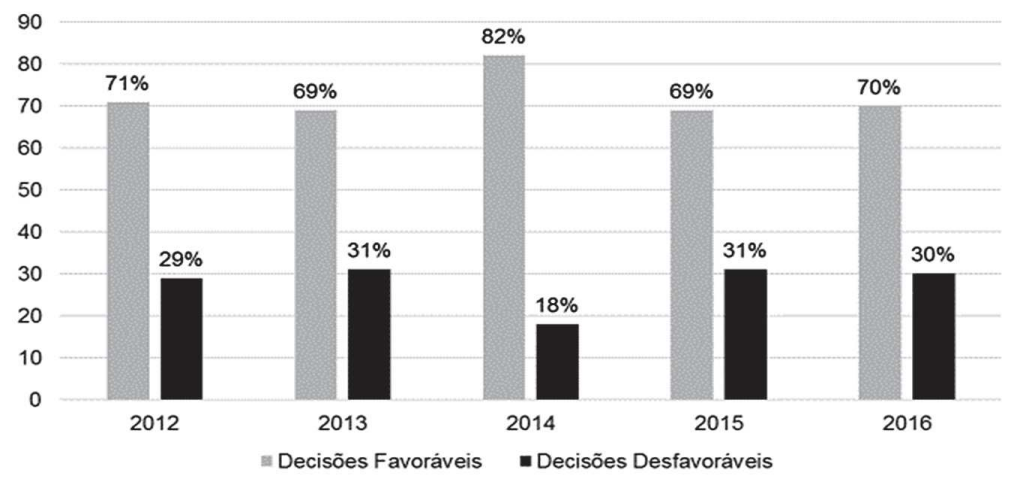

Fonte: Balanço do Cade de $2016 .^{49}$

48 BRASIL. Conselho Administrativo de Defesa Econômica. Balanço 2016. p. 33. Disponível em: $<$ www.cade.gov.br/servicos/imprensa/balancos-e-apresentacoes/apresentacao-balanco-2016. pdf/@@download/file/Apresenta\%C3\%A7\%C3\%A3o-Balan\%C3\%A7o\%20-\%202016.pdf>. Acesso em: 9 jul. 2018.

49 Ibid. 
Portanto, ao que se vê, a nova Lei Antitruste, 12.529/2011, suscitou, para além das conquistas normativas de quase 50 anos do Cade e 17 anos da Lei no 8.884/1994, ambiguidades e dissensos que acabaram nas barras dos Tribunais. Consequência primordial dessa constatação é a imperiosa necessidade de que os juízes federais atuantes em Brasília e que estejam atuando na solução das lides concorrenciais devem aprimorar-se no conhecimento jurídico-econômico, mormente, concorrencial, e acautelarem-se nos ensinamentos advindos da tomada de decisão administrativa dos experts que atuam no Tade, como forma de evitarem-se infinitos recursos protelatórios ou a natural morosidade do processo judicial que leva à inoperância - ineficiência - do Judiciário que, não raras vezes, é utilizado de forma utilitária pelos grandes players econômicos que, antes de raciocinar segundo um "direito romântico" aos moldes da antiga tradição civilista brasileira dos séculos XIX e XX, por assim dizer, maximizam oportunidades e racionalizam a tomada de decisão para defesa de seus interesses em pleno século XXI e em um mundo globalizado e neoliberal flexibilizador das relações de produção que pugna pela, também, flexibilização da normatividade e da decisão administrativa ou judicial que favoreça a inexorável expansão de mercado a qualquer custo. É o que não se espera, seja do Cade ou do Juízo Federal de primeira instância; ou seja, por outro lado, espera-se o julgamento que, para além do exercício do poder, implique justiça econômico-social aos moldes do princípio da eficiência econômico-social.

\section{Considerações finais}

Trilhado o caminho metodológico proposto e dentro de perspectiva realista de análise de dados empíricos, analisaram-se as possibilidades de procedimentos administrativos que podem ser instaurados perante o Cade para o controle de estruturas e de condutas infracionais no mercado brasileiro, bem como o constitucional direito de acesso à justiça seja pelo próprio Cade, seja pelo agente econômico; ato contínuo, discutiu-se a possibilidade de revisão judicial das decisões administrativas e, em especial, a revisão judicial das decisões proferidas pelo Cade segundo números estatísticos advindos, especialmente, do próprio Cade e da Sociedade Brasileira de Direito Público.

O trabalho foi realizado com o objetivo de analisar se, e em que medida, as decisões proferidas pelo Cade são passíveis de revisão perante o Poder Judiciário. A verificação se deu por duas vias distintas. Primeiramente, 
buscou-se analisar a posição doutrinária acerca da revisão judicial de atos administrativos. Após, foram apresentados dados empíricos sobre a judicialização das decisões proferidas pelo Cade.

Doutrinariamente, percebeu-se a presença de um dissenso acerca da amplitude da revisão judicial dos atos administrativos discricionários. Nem mesmo o princípio da inafastabilidade da jurisdição foi capaz de trazer unanimidade à questão. Especificamente acerca das decisões proferidas pelo Cade, a ausência de consenso se manifesta: (i) sobre a natureza discricionária dos atos emitidos pela autarquia, e (ii) à extensão do controle a ser exercido pelo Judiciário.

Diferentemente, a partir da análise dos dados empíricos, verificou-se que: (i) a cada ano aumenta o número de ações que são ajuizadas contra o Cade, (ii) as ações questionam não só pontos estritamente formais, mas, também, o mérito dos atos, (iii) o Cade possui índice de "vitórias" perante o Poder Judiciário considerável, (iv) as decisões judiciais revisam o mérito, a forma, e ambas as esferas conjuntamente, e (v) as sentenças, decisões interlocutórias e acórdãos proferidos apresentam vícios, como a sobrevalorização de questões processuais, a falta de expertise técnica, a presença de um viés privatista e a insensibilidade às razões regulatórias do Órgão Antitruste, por excelência, abalizado para a decisão que garanta o mercado concorrencial.

Partindo da perspectiva de que a atuação do Cade não se dá de forma meramente discricionária, defende-se a sindicabilidade judicial das decisões proferidas pelo Cade de forma ampla. Todavia, critica-se a eventual falta de conhecimento técnico na área antitruste ou inadequação institucional do Poder Judiciário bem como sua morosa atuação para o tratamento de ações judiciais referentes à revisão de decisões administrativas do Cade. Defende-se, pois, a necessidade da criação de varas especializadas para análise de lides que versem sobre concorrência ou, quiçá, a estruturação de efetivo Tribunal Judicial de Concorrência.

\section{Referências}

BRASIL. Conselho Administrativo de Defesa Econômica. Balanço 2016. Disponível em: <www.cade.gov.br/servicos/imprensa/balancos-e-apresentacoes/ apresentacao-balanco-2016.pdf/@@download/file/Apresenta\%C3\%A7\%C3\% A3o-Balan\%C3\%A7o\%20-\%202016.pdf>. Acesso em: 9 jul. 2018. 
Constituição da República Federativa do Brasil de 1988. Disponível em: $<$ www.planalto.gov.br/ccivil_03/constituicao/constituicao.htm>. Acesso em: 9 jul. 2018.

Decreto $n^{\circ}$ 9.266, de 15 de janeiro de 2018. Altera o Decreto $n^{\circ}$ 9.003, de 13 de março de 2017, que aprova a Estrutura Regimental e o Quadro Demonstrativo dos Cargos em Comissão e das Funções de Confiança do Ministério da Fazenda, remaneja cargos em comissão e funções de confiança, substitui cargos em comissão do Grupo-Direção e Assessoramento Superiores - DAS por Funções Comissionadas do Poder Executivo - FCPE, e altera o Decreto no 9.075 , de 6 de junho de 2017, que dispõe sobre a composição e as competências da Comissão de Financiamentos Externos. Disponível em: <www.planalto.gov.br/ccivil_03/_ato2015-2018/2018/decreto/D9266.htm>. Acesso em: 3 ago. 2018.

Lei 9.784, de 29/01/1999, que regula o processo administrativo no âmbito da Administração Pública Federal. Disponível em: <www.planalto.gov.br/ ccivil_03/leis/19784.htm>. Acesso em: 9 jul. 2018.

Lei $n^{0}$ 12.529, de 30 de novembro de 2011. Estrutura o sistema brasileiro de defesa da concorrência. Disponível em: <www.planalto.gov.br/ccivil_03/_ ato2011-2014/2011/Lei/L12529.htm>. Acesso em: 9 jul. 2018.

Ministério da Fazenda. Secretaria de Acompanhamento Econômico - Seae. Disponível em: <www.fazenda.gov.br/orgaos/seae>. Acesso em: 3 ago. 2018.

BULOS, Uadi Lammêgo. Curso de direito constitucional. 9. ed. rev. e atual. de acordo com a Emenda Constitucional n. 83/2004, e os últimos julgados do Supremo Tribunal Federal. São Paulo: Saraiva, 2015.

CARVALHO FILHO, José dos Santos. Manual de direito administrativo. 28. ed. rev., ampl. e atual. São Paulo: Atlas, 2015.

CARVALHO, Matheus. Manual de direito administrativo. 4. ed. rev., ampl. e atual. Salvador: JusPodivm, 2017.

COELHO, Fábio Ulhoa. Curso de direito comercial: direito de empresa. 12. ed. São Paulo: Saraiva, 2011. v. 3.

FAGUNDES, Miguel Seabra. O controle dos atos administrativos pelo Poder Judiciário. 8. ed. Rio de Janeiro: Forense, 2010.

FARIA, Edimur Ferreira de. Controle do mérito do ato administrativo pelo judiciário. Belo Horizonte: Fórum, 2011. 
FORGIONI, Paula A. Os fundamentos do antitruste. 8. ed. rev. e atual. São Paulo: Revista dos Tribunais, 2015.

GABAN, Eduardo Molan; DOMINGUES, Juliana Oliveira. Direito antitruste. 4. ed. São Paulo: Saraiva, 2016.

GONÇALVES, Everton das Neves; STELZER, Joana. Principle of social and economic efficiency (Psee) at the Brazilians law: the normative and judicial decision taking. Sequencia: Estudos Jurídicos e Políticos, s.l., v. 35, n. 68, p. 261-290, jun. 2014. Disponível em: <https://periodicos.ufsc.br/index.php/ sequencia/article/view/2177-7055.2013v35n68p261/26955>. Acesso em: 9 jul. 2018.

GONÇALVES, Marcus Vinicius Rios. Direito processual civil esquematizado. São Paulo: Saraiva, 2011.

LIMA, Eduardo Garcia. O controle judicial das decisões do Cade. Revista Eletrônica Sapere Aude. Disponível em: <http://revistasapereaude.org/index. php/edicoes/anos-anteriores/ano-4-vol-1-12/ano-4-volume-4-novembro-2015/ send/88-11-2015-ano-4-volume-4/307-j-o-controle-judicial-das-decisoes-docade-pg-180-203>. Acesso em: 9 jul. 2018.

MARANHÃO, Juliano Souza de Albuquerque; AZEVEDO, Paulo Furquim; FERRAZ JUNIOR, Tercio Sampaio. Direito regulatório e concorrencial no Poder Judiciário. São Paulo: Singular, 2014.

MAZZA, Alexandre. Manual de direito administrativo. São Paulo: Saraiva, 2016.

MELLO, Celso Antônio Bandeira de. Curso de direito administrativo. 26. ed. rev. e atual. São Paulo: Malheiros, 2009.

PINHO, Humberto Dalla Bernadina de. Direito processual civil contemporâneo, volume I: teoria geral do processo. 4. ed. São Paulo: Saraiva, 2012.

PORTO, Catarina Mota de Figueiredo. Decisões do Cade eprincípios constitucionais na ordem econômica. Disponível em: <www.fap-pb.edu.br/instituto/arquivos/ revista_juridica_2015_artigo6.pdf>. Acesso em: 9 jul. 2018.

ROCHA, Frederico. Dinâmica da concentração de mercado na indústria brasileira, 1996-2003. Economia e Sociedade, Campinas, v. 19, n. 3 (40), p. 477498, dez. 2010. Disponível em: <https://periodicos.sbu.unicamp.br/ojs/index. php/ecos/article/view/8642677/10157>. Acesso em: 3 ago. 2018.

SILVA, José Afonso da. Curso de direito constitucional positivo. 15. ed. rev. e atual. São Paulo: Malheiros, 1998. 
SOCIEDADE BRASILEIRA DE DIREITO PÚBLICO (SBDP). Revisão judicial das decisões do Conselho Administrativo de Defesa Econômica (Cade): pesquisa empírica e aplicada sobre os casos julgados pelos Tribunais Regionais Federais (TRFs), Superior Tribunal de Justiça (STJ) e Supremo Tribunal Federal (SFT). Belo Horizonte: Fórum, 2011. 